\title{
Increased sensitivity of lymphocytes from patients with systemic autoimmune diseases to DNA alkylation by the methylating carcinogen $N$-methyl- $N$-nitrosourea
}

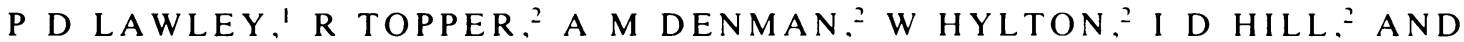 \\ G HARRIS ${ }^{3}$
}

From the 'Institute of Cancer Research, Royal Cancer Hospital, Chester Beatty Laboratories, London; the 'Clinical Research Centre, Northwick Park Hospital, Harrow, Middlesex; and the "Kennedy Institute of Rheumatology, London

SUMMARY Lymphocytes from patients with various diseases associated with autoimmunity showed both impaired capacity to repair $O^{6}$-methylguanine (a powerful, promutagenic, directly miscoding base lesion) and increased sensitivity to the cytocidal effects of cellular methylation by $N$-methyl- $N$-nitrosourea (MNU) compared with normal controls and patients with other disorders. Defective repair of $O^{6}$-methylguanine was significantly associated with arthritis and myositis in the group with systemic lupus erythematosus (SLE), and increased sensitivity to the toxic action of MNU was associated with the presence of immune complexes and the administration of steroids to patients with Behçet's syndrome. The results indicate that lymphocytes from patients with the autoimmune diseases studied are more susceptible to DNA damage with possible relevance to aetiopathogenesis.

Key words: DNA repair, mutation, rheumatoid arthritis, SLE.

Autoimmune diseases have a multifactorial pathogenesis with a genetic basis. The potent carcinogenic agent $N$-methyl- $N$-nitrosourea (MNU) alkylates DNA to form a powerful promutagenic base lesion. $O^{6}$-methylguanine $\left(O^{6}\right.$-MeGua $)$, which has been found to induce the development of autoimmunity in susceptible strains of inbred mice, haemolytic anaemia and $T$ cell malignancies being the main clinical features. ' Murine lymphocytes are severely defective in the repair of $O^{6}$-MeGua while lymphocytes from healthy human donors are relatively proficient. ${ }^{2}$ This repair activity has been studied in cells from patients with autoimmune diseases and they also showed evidence of defective DNA repair. ${ }^{3}$

This paper assesses DNA repair in a larger population of people with autoimmune diseases and examines the results in relation to the clinical features of the diseases.

Accepted for publication 16 December 1987.

Correspondence to Dr A M Denman. Clinical Rescarch Centre. Northwick Park Hospital. Harrow. Middlesex HAI 3UJ.

\section{Patients and methods}

PATIENTS

A total of 245 individuals were studied in the following categories:

(a) Systemic lupus erythematosus (SLE). Forty eight patients satisfying Arthritis and Rheumatism Association criteria. ${ }^{+}$Disease duration was four months to 38 years (mean 8.2 years).

(b) Rheumatoid arthritis (RA). Twenty one patients satisfying the diagnostic criteria of Ropes et al. ${ }^{5}$ Disease duration was two months to 20 years (mean $6 \cdot 4$ years).

(c) Behçet's syndrome. Fifty three patients with established diagnostic features." Disease duration was nine months to 36 years (mean $10 \cdot 6$ years). (d) Scleroderma. Thirteen patients who fulfilled the diagnostic criteria of Masi et al. ${ }^{7}$ Disease duration was six months to 17 years (mean 10.() years).

(e) Miscellaneous autoimmune diseases. Thirty eight patients, including cases of myositis, polyarteritis nodosa, Sjögren's syndrome, and unclassified 
polyarthritis. Disease duration was one month to 11 years (mean 2.9 years).

( $f$ ) Hospital controls. Fifty three patients with miscellaneous non-autoimmune conditions such as pneumonia, myocardial infarction. carcinomas of lung, colon. etc were studied. Disease duration was one month to 42 vears (mean 6.5 vears).

(g) Healthy controls. Twenty three healthy laboratory staff were used (aged 21-56. mean 34 vears). Blood samples were obtained with approval of the ethical committee of Northwick Park Hospital.

TOXICITY STLI)IES

Human mononuclear cells were obtained from peripheral blood by density gradient separation. For toxicity studies lymphocytes were cultured in $3 \mathrm{ml}$ volumes $\left(0.5 \times 10^{\text {th }}\right.$ cells $\left./ \mathrm{ml}\right)$ in RPMI $\left.16+0\right)$ medium supplemented with $5 \%$, fetal calf serum and $(0.15 \mathrm{mM}$ 2-mercaptoethanol in flat bottomed 'Linbro' tissue culture plates. Concanavalin A (con A) was added (Sigma: $+\mu \mathrm{g} / \mathrm{ml}$ ) at the start of the culture period. Cell counts were made on day 7 . the time of maximal increase in cell numbers. MNU was added at the beginning of culture in varying concentrations and was not removed in view of its short half life of $<15$ minutes. Results are the means of triplicate cultures. The assessment of toxicity was carried out on coded samples.

\section{CHEMICAL METHODS}

The carcinogen. MNU. was prepared by nitrosation of its methylurea and used as described in detail previously. ${ }^{\prime}$ In principle. cells suspended in isotonic saline $(\mathrm{pH} 6.4)$ at a concentration of $5-10 \times 10^{6}$ cells/ml were exposed to $N-\left[{ }^{1+} \mathrm{C} \mid\right.$ methyl- $N$-nitrosourea $\left(\left[{ }^{1+} \mathrm{C}\right] \mathrm{MNU}\right)$ (Amersham International plc. Amersham. Bucks), specific activity $2.26 \mathrm{GBq} / \mathrm{mmol}$. As removal of $O^{h}$-MeGua is rapid in proficient cells the period of exposure was one hour." DNA was extracted and chromatographed as previously described using high performance liquid chromatography. ${ }^{*}$ The radioactivity in one minute fractions. indicated by the ultraviolet (UV) absorption of added marker methylpurines, was determined by liquid scintillation counting. The amount of DNA was determined from the UV absorption of guanine $(\varepsilon \max 11400)$ and adenine $(\varepsilon \max 13100)$, and the amounts of methylpurines after exposure to $\left[{ }^{1+} \mathrm{C}\right] \mathrm{MNU}$ were thus determined and expressed as $\mu \mathrm{mol} / \mathrm{mol}$ DNA-P. The ratio of $O^{6}-\mathrm{MeGua}$ to 7 MeGua in DNA was taken as an indicator of proficiency of removing $O^{6}$-MeGua from methylated cellular DNA as the removal of 7-MeGua is slow even in normal lymphocytes. ${ }^{2} 3$

STATISTICAL METHODS

In seeking any altered susceptibility of lymphocytes from patients with autoimmune disease to inhibition of growth by $\mathrm{MNU}$ the following points werc assessed: (a) replicate assays on the same sample? (b) variations between sequential samples from the same donor: and (c) differences between patient and control groups. taking into account botlo diagnostic and disease features.

Equivalent normal deviates (ENDs) were calcu殅 lated, as (patient value-control mean)/control SD $\overrightarrow{0}$ to determine which curves of inhibition of grow th be MNU were significantly abnormal. In this wais results were obtained which were observations fromo a distribution with mean ().() and SD $1 \cdot()$ if there were no differences between patients and controls: Comparison of the results with tables of the stanos dard normal curve therefore gives a probability that is comparable across all observations.

The computer program 'GLIM' was used to analyse any differences between donor groups in the growth of con A stimulated lymphocvtes unexpose to $\mathrm{MNU}$. This response to con A was examined in relation to age and sex of the patients and controls $\overrightarrow{0}$

The ratio $\left(\left(^{\prime \prime}-\mathrm{Me}\right.\right.$ Gual)/(7-MeGua). used as allpo index of repair of ()$^{\prime \prime}$-MeGua by treated lymphog cytes." was analysed by Student 's $t$ test. The ratios were examined in relation to clinical features bo stepwise multiple regression using the computeg program 'Minitab'.

Any missing values were replaced by randon values taken from the distribution of recordec values. To assess the effect of this technique eaclg run was performed five times using different randorof numbers. and no substantial changes were found as a result.

\section{Results}

\section{TOXICIT)}

Lymphocytes from all donors proliferated in re음 sponse to con A. more than doubling in numbed during seven days of culture, and this response waㄹ. not significantly affected by age. sex, or disease. The ability of cultured human lymphocytes to divide in response to con A after initial damage by $\mathrm{MNU}$ was impaired in patients with autoimmune disease compared with healthy donors or patients withou? evidence of autoimmune disease (Fig. 1). The results were calculated as percentages of the growth of control cultures not exposed to MNU as previously described.?

The in vitro sensitivity of lymphocytes from thes옹 patients to varying concentrations of MNU was studied taking into account their clinical status an $\mathbb{B}$ the results of their laboratory investigations. For this purpose for each patient the inhibition of growth ad each concentration of MNU was compared with the 
mean and standard deviation of the percentage inhibition of growth of the healthy control group. Up to five results corresponding to the concentrations of MNU added to the cultures were used for each patient and from these results the equivalent

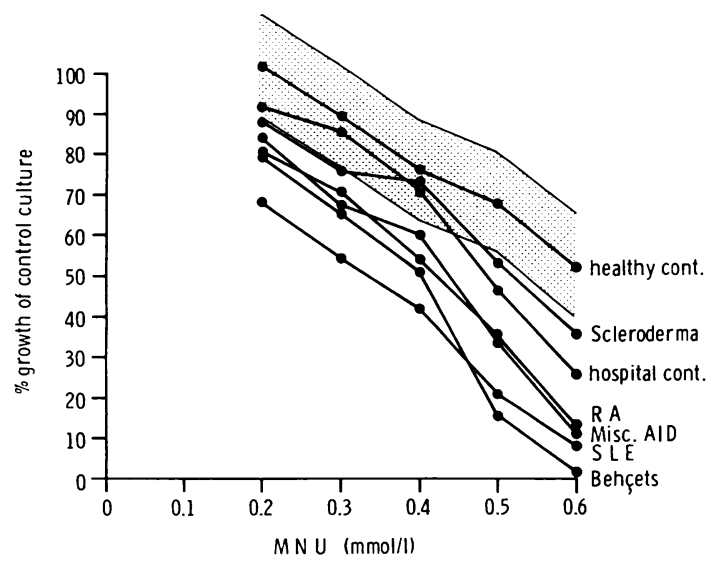

Fig. 1 The inhibitory effect of varying concentrations of $N$-methyl-N-nitrosourea (MNU) on the growth of human lymphocytes in response to con $A$, expressed as percentage of the growth of untreated cultures. The mean growth curve for each disease group is shown. The shaded area represents the $95 \%$ confidence limits for the healthy controls.

Table 1 Range of equivalent normal deviates (ENDs) for inhibition of lymphocyte growth by $N$-methyl-N-nitrosourea

\begin{tabular}{ll}
\hline Group & ENDs \\
\hline SLE & 1.60 to -17.79 \\
RA & 1.96 to -7.54 \\
Bchçet's & 0.74 to -9.57 \\
Scleroderma & 1.95 to -6.55 \\
$\begin{array}{l}\text { Miscellaneous autoimmune } \\
\text { discases }\end{array}$ & 1.27 to -8.00 \\
Hospital controls & 1.87 to -9.59 \\
Healthy controls & 1.87 to -6.95 \\
\hline
\end{tabular}

The ENDs were calculated as indicated in the text. normal deviate (END) for each patient was calculated (Table 1).

Fig. 2 shows the range of END values for healthy controls and for patients with Behçet's syndrome. Most of the healthy controls had ENDs between 2 and -1 as compared with only $15 \%$ of the donors with Behçet's syndrome. Similar distributions (not shown) were found for the other autoimmune groups.

The ENDs from all the autoimmune disease groups were taken together and put into numerical order and divided into three equal groups, to allow comparison between groups I and III (Table 2). The results in patients with autoimmune disease showed a wide range of values, but significant numbers showed increased cellular sensitivity to the toxic action of MNU (Table 2).

Clinical features and laboratory results were analysed in relation to these toxicity studies (Table 3 ). Increased sensitivity of blood lymphocytes to

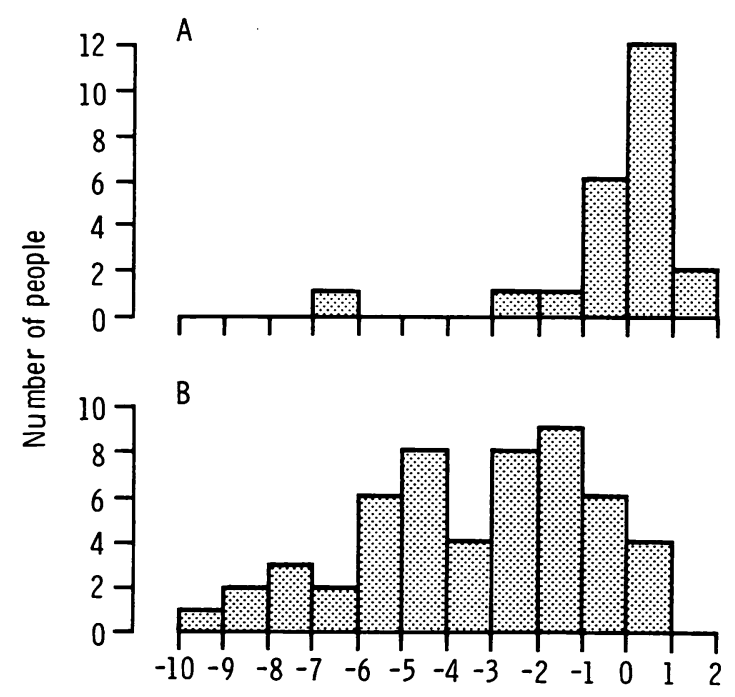

Fig. 2 Histograms showing the distribution of ENDs for $(A)$ the healthy controls and $(B)$ the group of patients with Behçet's syndrome.

Table 2 The range of equivalent normal deviates (ENDs) for toxicity of $N$-methyl-N-nitrosourea to lymphocytes from patients with autoimmune diseases

\begin{tabular}{lcrr}
\hline Disease & $\begin{array}{l}\text { Group I } \\
(I .96 \text { to }-I \cdot 17)\end{array}$ & $\begin{array}{l}\text { Group II } \\
(-I \cdot I 7 \text { to }-3 \cdot 79)\end{array}$ \\
\hline SLE & 17 & 14 & 17 \\
RA & 7 & 8 & 6 \\
Behçet's & 13 & 17 & 23 \\
Scleroderma & 8 & 4 & 1 \\
Miscellaneous autoimmune & 16 & 13 & 9 \\
\hline
\end{tabular}

The ENDs were calculated and the results were grouped as indicated in the text. 
MNU was associated with circulating immune complexes and treatment with steroids. Conversely, significantly more patients who had shown low levels of serum $\operatorname{IgG}(<8.9 \mathrm{~g} / \mathrm{l})$ during the course of their disease were found to be in group I (i.e.., the group most nearly resembling the controls) rather than group III.
DNA REPAIR STUDIES

Fig. 3 shows the products of methylation of bloof lymphocyte DNA with $\left[{ }^{1+} \mathrm{C}\right] \mathrm{MNU}$ in the chromato= gram from a patient with SLE one hour after initias exposure. There was deficiency of $O^{6}-\mathrm{MeGua}$ repai while 3-methyladenine was proficiently removed $\overrightarrow{\widetilde{\Phi}}$ The removal of 7-MeGua was slow and there was no

Table 3 Summary of sensitivity to $N$-methyl-N-nitrosourea (MNU) in relation to clinical features and laboratory resulson

\begin{tabular}{|c|c|c|c|}
\hline Disease & Summary of sensitivity & Group 1 & Grolup III \\
\hline SLE & $\begin{array}{l}\text { More patients with alopecia } \\
\text { were in group III }(p=0 \cdot 057) \\
\text { Significantly more patients in } \\
\text { group I than group III showed } \\
\text { altered levels of serum } \\
\text { (immunoglobulins }(p=0 \cdot(0) 43) \\
\text { This was also true for IgA } \\
(p=() \cdot(181)\end{array}$ & $12 / 14$ & $\begin{array}{l}3 / 12 \\
1 / 12\end{array}$ \\
\hline RA & $\begin{array}{l}\text { More patients with vasculitis were } \\
\text { found in group III than in group I } \\
(p=(1 .(145)\end{array}$ & (1)/7 & $3 / 5$ \\
\hline Bchçet's & $\begin{array}{l}\text { A higher proportion of patients in } \\
\text { group III were taking steroids than } \\
\text { in group } I(p=0) \cdot 082)\end{array}$ & $3 / 20$ & $8 / 19$ \\
\hline Scleroderma & $\begin{array}{l}\text { Older patients }(>4) \text { years) were } \\
\text { found in group I (only } 14 \text { patients } \\
\text { were studied) }(\mathrm{p}=(0 .(1) 48)\end{array}$ & $4 / 5$ & $01 / 4$ \\
\hline $\begin{array}{l}\text { Miscellaneous } \\
\text { autoimmune }\end{array}$ & $\begin{array}{l}\text { Significantly more patients with } \\
\text { circulating immune complexes at } \\
\text { some point in their illness were } \\
\text { found in group III than in group I } \\
(p=() \cdot(15)(1)\end{array}$ & $1 / s$ & $6 / 9$ \\
\hline
\end{tabular}

*Figures are (number with stated feature)/(number in each group).

No relation was found between MNU sensitivity and (a) presence or severity of arthritis. cardiovascular. pulmonary. skin. renci⿱⺈ gastrointestinal, or central nervous svstem features: (b) disease duration: (c) treatment with non-steroidal anti-inflammatory drugs, gol@ or penicillamine (RA) or cytotoxic drugs (all diseases); and (d) haemoglobin. white cell count. erythrocyte sedimentation rate immunoglobin concentration, complement levels. immune complexes. and autoantibodies.

Table 4 Repair of $O^{\prime}$-methylguanine $\left(O^{\prime \prime}-M e G u a\right)$ in human lymphocytes

\begin{tabular}{|c|c|c|c|c|c|c|}
\hline \multirow[t]{2}{*}{ Disease } & \multirow[t]{2}{*}{$n$} & \multicolumn{2}{|c|}{$O^{h}-M e G u a / 7-M e G u a$} & \multirow[t]{2}{*}{$t$ Value } & \multirow{2}{*}{$\begin{array}{l}\text { Degrees of } \\
\text { freedom }\end{array}$} & \multirow[t]{2}{*}{ Probability } \\
\hline & & Mean & $S D$ & & & \\
\hline SLE & 29 & 0.068 & ()$\cdot() 12$ & $-2 \cdot 41$ & 44 & $0 \cdot(020$ \\
\hline RA & 15 & $0 \cdot(070$ & $0 \cdot(010$ & $-3 \cdot 20$ & 30 & $0.0(0) 3$ \\
\hline Behçet's & 17 & $0 \cdot() 69$ & $0 \cdot 012$ & $-2 \cdot 77$ & 45 & $0 \cdot()(0)$ \\
\hline Scleroderma & 5 & 0.0 .58 & $0 \cdot 006$ & $(0.51$ & 20 & 0.616 \\
\hline Miscellaneous autoimmune & 18 & 0.069 & $(0 \cdot 010$ & $-2 \cdot 86$ & 33 & $0 \cdot 0017$ \\
\hline Hospital controls & 17 & $0.1) 63$ & $0 \cdot() 10$ & -0.94 & 32 & 0.354 \\
\hline Healthy controls & 17 & $(1) \cdot(1) 6()$ & 0.008 & - & - & - \\
\hline
\end{tabular}

The means and standard deviations for each group of the ratio ( $O^{\prime \prime}$-MeGua $) /(7-M e G u a)$ in lymphocytes obtained from the peripheral blood one hour after initial exposure to $\left.0.1 \mathrm{mM}\right|^{1+} \mathrm{C} \mid \mathrm{MNU}$ are shown. The $t$ tests done between the healthy control group and each patient groug are also tabulated 
significant removal in the first 24 hours after exposure to MNU. Proficient cells would be expected to remove around $50 \%$ of $O^{6}-\mathrm{MeGua}$ from their DNA during the first hour after initial expo-

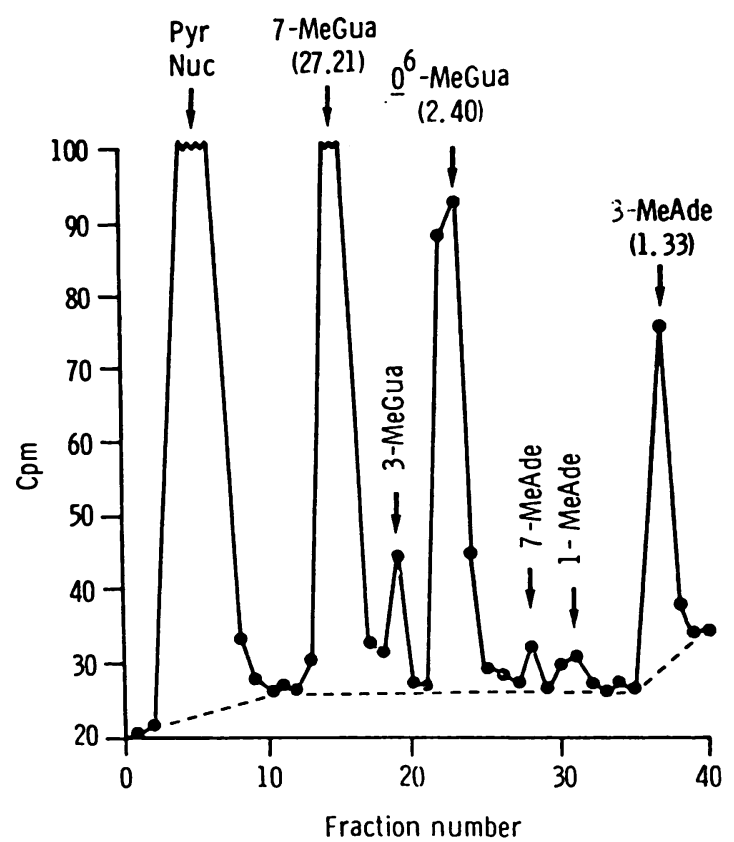

Fig. 3 A typical chromatogram showing the methylation products found in DNA isolated from deficient lymphocytes from a patient with SLE treated in vitro one hour previously with $N$-methyl-N-nitrosourea (MNU). Extent of MNU methylation of lymphocyte DNA $\mu \mathrm{mol} / \mathrm{mol}$ phosphorus is shown in brackets. sure to $\left[{ }^{1+} \mathrm{C}\right] \mathrm{MNU}$ giving a ratio of $O^{6}-\mathrm{MeGua}$ to 7 MeGua of $0 \cdot 055$. In the example shown in Fig. 3 this value was $0 \cdot 088$.

Control donors had generally lower ratios than the other groups, indicating more proficient repair of $O^{6}$-MeGua (Fig. 4). Significant differences were found between the healthy control group and donors with Behçet's syndrome, SLE, RA, and the group of miscellaneous autoimmune diseases but not scleroderma (Table 4).

When repair proficiency of $O^{6}$-MeGua was analysed in terms of specific clinical and laboratory findings arthritis in the group with SLE, myositis in the group with miscellaneous autoimmune diseases, and disease activity in the group with RA were significantly associated with reduced $O^{6}$-MeGua repair (Table 5).

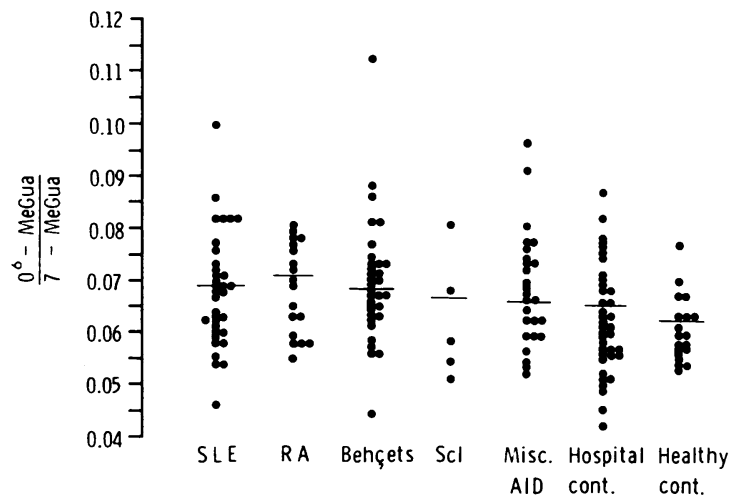

Fig. 4 Ratios of $\left(O^{\prime \prime}-M e G u a\right) /(7-M e G u a)$ in DNA of human lymphocytes isolated one hour after the addition of $I^{1+} C I M N U$.

Table 5 Summary of significant defects in repair of $O^{\prime \prime}$-methylguanine, as indicated by $\left(O^{\prime \prime}\right.$-MeGua)/(7-MeGua), in relation to clinical features and laboratory results

\begin{tabular}{|c|c|c|c|}
\hline Disease & $\begin{array}{l}\text { Relation to clinical } \\
\text { features }\end{array}$ & $\begin{array}{l}1 \text { Value } \\
\text { idegrees of } \\
\text { freedom) }\end{array}$ & Probability \\
\hline SLE & $\begin{array}{l}\text { There appeared to be a } \\
\text { significant positive relation } \\
\text { with arthritis }\end{array}$ & $\begin{array}{l}2 \cdot 16 \\
(26)\end{array}$ & 0.05 \\
\hline RA & $\begin{array}{l}\text { A significant negative } \\
\text { relation with discase } \\
\text { activity }\end{array}$ & $\begin{array}{l}-3 \cdot 53 \\
(14)\end{array}$ & $0 \cdot(0) 3$ \\
\hline Bchçet's & Nil & & \\
\hline Sclcroderma & Nil & & \\
\hline Miscellaneous autoimmune & $\begin{array}{l}\text { A significant positive } \\
\text { relation with myositis }\end{array}$ & $\begin{array}{l}2 \cdot 8 \\
(25)\end{array}$ & 0.05 \\
\hline Hospital controls & Nil & & \\
\hline
\end{tabular}

No correlation with discase features listed in footnote to Table 3 . 


\section{Discussion}

These results extend preliminary observations indicating that autoimmune diseases may be associated with at least one form of impaired DNA repair proficiency. ${ }^{3}$ In addition to establishing this association in several such disorders, increased sensitivity to MNU could be correlated with specific disease features. The association between steroid treatment in Behçet's syndrome and increased susceptibility may reflect disease severity rather than a direct effect of steroid treatment on lymphocytes as a similar association was not found in other autoimmune diseases.

The concept of somatic mutation as a basis for autoimmune disease is an extension of the clonal selection hypothesis of antibody formation." It is now established that somatic DNA recombination ${ }^{11}$ and point mutations " are involved in physiological B cell differentiation and expression of immunoglobulin genes. Although somatic mutation is important for normal antibody synthesis, however, a specific $\mathrm{V}$ gene mutation in a cell line has been found to give rise to antibody with autoantibody specificity. ${ }^{12}$ Thus similar mutations could give rise to autoantibody production in human disease.

The formation in DNA of a potent promutagenic base lesion, $O^{6}$-MeGua, is associated with the development of autoimmune haemolytic anaemia in susceptible strains of mice. ${ }^{\prime} O^{h}$-MeGua in DNA is repaired by direct reversal with conversion back to guanine. The rate of repair of this lesion is important in determining the extent of mutation ${ }^{13}$ as cell division by unrepaired cells results in direct miscoding during DNA replication, thymidine instead of cytidine pairing with $O^{6}$-MeGua. Furthermore. murine lymphocytes are deficient in removing $O^{6}$. MeGua from DNA. ${ }^{2}$ Thus it was logical to study the responses to MNU of lymphocytes from patients with autoimmune diseases as reduced repair proficiency and altered sensitivity may indicate increased susceptibility to potent environmental mutagens relevant to the pathogenesis of these disorders.

The results show that blood lymphocytes from patients with certain autoimmune diseases are relatively deficient in the repair of $O^{6}-\mathrm{MeGua}$ and also show increased sensitivity to the toxic effects of MNU compared with normal subjects and patients with other disorders. There was considerable overlap and this reduced proficiency does not absolutely discriminate between patients with autoimmune diseases and other individuals. It may, however, identify a risk factor analogous with inherited complement deficiency.

It is unlikely that reduced repair proficiency simply reflects the effects of non-specific factors such as inflammatory mediators or changes in $\overrightarrow{\vec{*}}$ circulating lymphocyte populations. Repair pro- $\frac{\vec{\sigma}}{0}$ ficiency in inflammatory diseases not associated with 등 autoimmunity was comparable with that in normal $\frac{\bar{c}}{\overline{0}}$ controls. T and non-T lymphocytes isolated from the $\overrightarrow{\mathbb{D}}$ same donor show identical repair proficiency. "In addition, the repair proficiency of Epstein-Barros virus transformed lymphoblastoid cell lines reflects $\overrightarrow{0}$ that of the blood lymphocytes from which such lines $\vec{\overrightarrow{ }}$ are obtained." Unequivocal DNA repair defects $\omega$ have been detailed in rare, usually inherited, disorders. ${ }^{1+}$ Similar evidence is sparse in auto-? immune diseases, though reduced repair proficiency. of UV induced damage in skin fibroblast DNA has been claimed in SLE. 15 in albeit with conflicting results. ${ }^{17}$ Blood lymphocytes from patients with $\mathrm{RA}_{0}$ and SLE proved abnormally sensitive to $x$ irradiation in vitro and were defective in repair of radiation induced DNA damage. ${ }^{\text {is }}$ It is noteworthy that concentrations of the relevant repair enzyme $O^{h}-$ alkylguanine-DNA alkyltransferase have been re- $\vec{\oplus}$ ported to be low in normal human myeloid cells 9 and this has been considered a risk factor in leukaemogenesis. ${ }^{1 "}$

Proficient repair of $O^{6}$-MeGua is not directly related to resistance to MNU toxicity as this mutagen induces several cytotoxic lesions. In par- $\mathbb{Q}$ ticular 3-MeAde is an important lesion but all $\overrightarrow{\vec{P}}$ human lymphocytes so far studied are proficient in $\exists$ its repair. ${ }^{8}$ Thus although the present data indicate that lymphocytes from patients with autoimmune diseases show increased sensitivity to $\mathrm{MNU}$ and deficient repair of $O^{6}$-MeGua, the two defects need not necessarily be related.

Cellular DNA repair defects of this kind could be genetically determined or result from external fac-o tors influencing cellular DNA repair, including virus infections. ${ }^{18}$ Failure to repair DNA damage ef-음 ficiently may produce an increased rate of somatic $D$ mutations in target cells with resultant autoimmune을 disease. ${ }^{17}$ Family studies are needed to distinguish between genetic and acquired factors.

\section{References}

1 Harris G. Lawley P D. Asberry L J. Chandler P M. Jones M G. $\sigma$ Autoimmune haemolytic disease in mice after exposure to aco methylating carcinogen. Immunology 1983; 49: 439-49.

2 Harris G. Lawley P D. Olsen I. Mode of action of methylating carcinogens: comparative studies of murine and human cells. Carcinogenesis 1981: 1: 4()3-11.

3 Harris G. Asberry L. Lawley P D. Denman A M. Hylton W. Defective repair of $O^{h}$-methylguanine in autoimmune diseases. Lancet 1982; ii: 952-6.

4 Tan E M. Cohen A S. Fries J F. et al. Revised criteria for the 8 classification of SLE. Arthritis Rheum 1982; 25: 1271-7.

5 Ropes M W, Bennett G A. Cobb S, Jacox R, Jessar R A. Revision of diagnostic criteria for rheumatoid arthritis. Bull $\mathrm{O}$ Rheum Dis 1958: 9: 175-6. 
6 Mason R M. Barnes C G. Behçet's syndrome with arthritis. Ann Rheum Dis 1969; 28: 95-103.

7 Masi A T. Rodnan G P. Medsger T A. Preliminary criteria for the classification of systemic sclerosis (scleroderma). Arthritis Rheum 1980; 23: 581-90.

8 Lawlcy P D. Harris G. Phillips E. et al. Repair of chemical carcinogen-induced damage in DNA of human lymphocytes and lymphoid cell line-studies of the kinetics of removal of $O^{6}$. methylguanine and 3-methyladenine. Chem Biol Interact 1986: 57: 107-21.

9 Burnet F. N. Intrinsic mutagenesis: a genetic basis of ageing. Pathology 1974; 6: 1-11.

10 Tonegawa S. Somatic generation of antibody diversity. Nature 1983; 302: $575-81$.

11 Griffiths G M. Berek C. Kaartinen M. Milstein C. Somatic mutation and the maturation of the immune response to 2phenyloxazolone. Nature 1984: 312: 271-5.

12 Diamond B. Scharff M D. Somatic mutation of the T15 heavy chain gives rise to an antibody with autoantibody specificity. Proc Natl Acad Sci USA 1984: 81: 5841-4.
13 Jeggo P. Isolation and characterisation of E. coli K12 mutants unable to induce the adaptive response to simple alkylating agents. J Bacteriol 1979; 139: 783-91.

14 Friedberg E C. Ehmann U K. Williams J I. Human diseases associated with defective DNA repair. Advances in Radiation Biology 1979: 8: 85-174.

15 Harris G. DNA damage and repair in immunologically active cells (II). Immunol Today 1983: 4: 109-12.

16 Theofilopoulos A N. Prud'homme G J. Dixon F J. Autoimmune aspects of systemic lupus erythematosus. In: J M Cruse. R E Lewis, eds. Current concepts in immunopathology. Vol. 1. Basel. New York: Karger. 1985: 190-218.

17 Cleaver J E. DNA damage and repair in light sensitive human skin disease. J Invest Dermatol 1970; 54: 181-95.

18 Harris G. Cramp W A. Edwards J C. et al. Radiosensitivity of peripheral blood lymphocytes in autoimmune disease. Int $J$ Radiat Biol 1985; 47: 689-99.

19 Genson S L. Miller K. Berter N A. $O^{6}$-Alkylguanine-DNA alkyltransferase activity in human myeloid cells. J Clin Invest 1985: 76: 2106-14. 